\title{
Development of Instruments to Measure Mathematical Anxiety of Elementary School Students
}

\author{
Hafiziani Eka Putri, Mukhammad Ady Wahyudy, \\ Aan Yuliyanto and Fitri Nuraeni \\ Universitas Pendidikan Indonesia, Indonesia \\ https://orcid.org/0000-0002-1325-1306 \\ https://orcid.org/0000-0001-9046-7875 \\ https://orcid.org/0000-0001-6257-127X \\ https:// orcid.org/0000-0002-2685-9812
}

\begin{abstract}
To generate high-quality research, a reliable instrument is required. This study aims to develop an instrument that can measure mathematical dimensions of elementary school students appropriately, for use in mathematics learning on spatial geometry. Each statement item in Mathematical Anxiety Instrument was developed based on 3 learning aspects, namely Attitudinal, Cognitive, Somatic. This study uses Research and Development (R\&D) method with a quasi-experimental design on geometry topic. The sample is 100 sixth grade students in an elementary school located in Karawang Regency. The instrument developed in this study is in the form of a questionnaire with closed-ended questions. The validity test analysis implies that 23 out of 30 items on the instrument are valid. This data is supported by Cronbach's Alpha test results, where all item has reliability value higher than 0.80 indicating that the instrument being tested has a very high-test reliability. Therefore, 23 items out of 30 items were developed into instruments for measuring mathematics anxiety that applicable in Mathematics learning activities. Thus, it leads to the conclusion that this mathematics anxiety questionnaire can be utilized as an instrument for future research.
\end{abstract}

Keywords: mathematical anxiety instrument; validity; reliability

\section{Introduction}

It is well known that mathematics is fundamental to children development and communication in future life. Basic numeracy skills assist children to have satisfactory achievement and further becoming a competent adult. A broader acknowledgment of this would lead to more parity with literacy. However, developing a strong foundation of early math skills is vital for children's later educational success as well as economic, health, and employment outcomes. 
Children entering school with strong mathematics skills have a greater likelihood of success in mathematics during kindergarten and in later grades. In Indonesia, Mathematics is formally taught at kindergarten until university. Currently, many teachers still teach mathematical topics using a teacher-centered approach, making the learning process seems to be rigid and boring. On the other side, deficient teaching of mathematics in kindergarten hinders the consolidation of basic mathematical knowledge, which is useful to children during their following school course. The absence of which, according to many researchers, is responsible to the extent of failure in mathematics (Papadakis et al., 2017).

Moreover, such instructions make students perceive mathematics as a subject that is difficult to understand and frightening. This condition is contrary to the expected competencies in mathematics subjects for elementary school levels (grades 1 to 4), which includes: (1) Conceptual understanding, which refers to understanding connected and operational mathematical concepts. Students with conceptual understanding able to understand mathematical facts and methods in depth. Understand the function of and how to use a mathematical concept; (2) Procedural fluency, namely procedural knowledge, knowledge of when and how to use them appropriately, and skills in doing so flexibly, accurately, and efficiently; (3) Strategic competence, which refers to the ability to formulate, describe and solve mathematical problems. Strategic competence plays an important role in every stage of procedural fluency development related to calculation. Strategic competence involves learning to replace complicated procedures with a more concise and efficient way; (4) Adaptive reasoning competence. It is interpreted as the ability to think logically about the relationship between concepts and situations; and (5) Productive disposition or the ability to be aware of the value of mathematics. It includes awareness that mathematics is useful and beneficial and believing that a great effort in learning mathematics will lead to excellent results and to see oneself as an effective learner and mathematician (National Research Council, 2001). If students want to develop conceptual understanding, procedural fluency, strategic competence, and adaptive reasoning abilities, they must believe that with diligent effort mathematics can be understood and can be used to overcome problems in daily life. These competencies can be developed well if students are comfortable and enjoy learning mathematics, instead of feeling afraid or anxious. Anxiety is included in the realm of attitude in mathematics that must be well developed. In line with this, one of the four objectives of the Mathematics learning is currently used curriculum is related to attitude development (Yuliyanto et al., 2019).

Students' are afraid of mathematics because the way they understand the material is not appropriate, especially at the beginning of the lesson. This fear might lead to difficulties in understanding mathematics and difficulties to focus on learning. Unfocused behavior is one of the mathematical anxiety indicators that include into cognitive aspect at a medium level (Putri, Muqodas, et al., 2019). There are many obstacles experienced by students in learning mathematics, one of which is mathematics anxiety (Afrianti \& Prabawanto, 2020). The significance of understanding mathematical anxiety lies in its potentially limiting effect on selfesteem and performance (Cropp, 2017). Therefore, students' mathematical anxiety can be defined as students' fear of mathematics. Anxiety appears when someone 
is in a particularly threatening situation. The same thing applies to children, where students might have high mathematical anxiety due to their prior experiences on the mathematics subject (Suarjana et al., 2017).

Mathematical anxiety also can affect students' daily life, academic performance, and even contribute to increasing students' stress, and if this condition continues, various problems might eventually happen (Shishigu, 2018). Math anxiety impacts students as early as the first grade by affecting their working memory (Aosi et al., 2019). Similarly, a study explains that mathematical anxiety is a problem that might give a negative effect on learning achievement and job prospects in the future. As compared to others with no or little mathematical anxiety, students with higher mathematical anxiety were lower in the following aspects: Socioeconomic-status, teacher-student relationship, self-efficacy, and mathematical problem-solving ability (Zhou et al., 2020). There are consequences for the students' anxiety inmathematics, and this interferes with their academic achievement. Students who experience mathematics anxiety typically refuse to enroll in mathematics courses or attending courses with important mathematical components that will influence their future career options (Alves et al., 2016). Furthermore, the negative relationship among mathematical anxiety and learning achievement in mathematics are possible because mathematical anxiety leads students to avoid Mathematics subject and might disrupt students' performance in solving particular mathematical problems (Ramirez et al., 2016). In this condition, it is assumed that there is a particular barrier that prevents knowledge transfer thus making students difficult to understand the materials being learned. One of the biggest constraints in mathematics learning is when students cannot understand the materials that are presented abstractly. In line with that, the word "abstract" in a question may also have encouraged slightly higher anxiety scores (Levere \& Kahlon, 2019). Handling student's anxiety is one of the mental health rehabilitation efforts that can overcome various obstacles in learning (Ardi et al., 2019).

High mathematical anxiety has an impact on mathematics learning achievement. Longitudinal research indicates that low attainment in mathematics can have significant long-term consequences, affecting later school achievement, employment, criminality, mental health, and future earnings. In many countries, underachievement in mathematics is strongly associated with social, cultural, and economic disadvantages. Yet, if the issue is settled it will lead to the opposite effect. Prior studies examining the longitudinal relations between number sense skills (e.g., counting, number knowledge, and number transformation) and later mathematics learning has shown promising results about the effect of mathematical anxiety on elementary and middle school mathematics achievement (Papadakis et al., 2018). Ashcraft and Kirk also said that individuals with high mathematics anxiety demonstrate smaller working memory spans, especially when assessed with a computation-based span task (Sevindir et al., 2014).

Mathematical anxiety includes fear, tension, and discomfort emotions felt by several individuals regarding mathematics and might interfere with one's performance in doing mathematics (Ashcraft \& Moore, 2009). Higher-level 
mathematics probably relies even more heavily on working memory, so may show a far greater impact of mathematics anxiety. As students dealing with challenging mathematical problems, then we can distinguish clearly the effects of high mathematics anxiety and low mathematics competence (Sevindir et al., 2014). Similarly, Tobias and Weissbrod (1980) describe mathematical anxiety as panic, helplessness, paralysis, and mental disorders that arise when solving mathematical problems. In line with that, mathematical anxiety can be defined as uncomfortable feelings arising from unstable emotional conditions that are characterized by fear, worry, anxiety, panic, etc. when someone is facing an unwanted task (Annisa \& Ifdil, 2016)

Moreover, particular physiological symptoms are somehow related to students' anxiety, which includes cardiovascular system (heart palpitations), breathing (shortness of breath, and a sense of strangulation), neuromuscular system (insomnia, and taut face), gastrointestinal system (loss of appetite, and diarrhea), urinary tract (cannot hold pee), and skin (facial blushing, and feeling chills on the skin) (Sunardi et al., 2019). It was also found that mathematics anxiety could affect the capacity of pre-service teachers to develop inclusive learning environments in their classrooms (Mizala et al., 2015).

A study done by Cavanagh and Sparrow (2010) divide mathematics anxiety into 3 domains, those are: 1) somatic; 2); cognitive and 3) attitude. Each domain was further broken down into three levels of mathematical anxiety (high, medium, and low) as seen on Table 1:

Table 1: Aspects, levels, and indicators of mathematical anxiety

\begin{tabular}{|c|c|c|}
\hline \multirow{4}{*}{ Aspect } & $\begin{array}{c}\text { Level of mathematical } \\
\text { anxiety }\end{array}$ & Indicator \\
\hline \multirow{4}{*}{ Attitudinal } & High & Afraid of what being done \\
\cline { 2 - 3 } & Medium & $\begin{array}{c}\text { Has no intention to do things that should } \\
\text { be done }\end{array}$ \\
\cline { 2 - 3 } & Low & $\begin{array}{c}\text { Expecting difficulties in doing particular } \\
\text { thing }\end{array}$ \\
\hline \multirow{3}{*}{ Cognitive } & High & $\begin{array}{c}\text { Worry of being judged by others that } \\
\text { she/he cannot do things well }\end{array}$ \\
\cline { 2 - 3 } & Medium & Has an empty mind \\
\cline { 2 - 3 } & Low & Feeling confused \\
\hline \multirow{3}{*}{ Somatic } & High & Difficult to breath \\
\cline { 2 - 3 } & Medium & Heart beats rapidly \\
\cline { 2 - 3 } & Low & Feeling uncomfortable \\
\hline
\end{tabular}

According to TIMSS results for Indonesian fourth grader, it is found that there are only $23 \%$ of students have a high confidence level in mathematics (TIMSS \& PIRLS Study Center, 2016). The average performance of these students is 440 placings in Indonesia in the bottom 8 out of 49 countries. The improper method in mathematics learning could make students difficult to understand the materials being learned, has negative experience during learning math, develop negative perspective toward mathematical things, and eventually resulting in mathematical anxiety (Kristanti \& Widyawati, 2009). 
One of the mathematical anxiety contributing factors is the type of instructional method used by teachers. Appropriate application of the teaching method can be in the form of an instructional approach that promotes mathematical problem solving and decrease students' mathematical anxiety. Students prefer mathematics teachers who enable them to exploit their misunderstanding of particular mathematics concepts. Teacher's patience and connection with students will greatly affect students' success in learning mathematics (Sofiatun et al., 2018). Therefore, mathematics instructions should change its image from mechanistic learning into enjoyable humanistic learning (Hendriana, 2012). Fun and enjoyable learning could make the learning process more effective. However, before lesson implementation, it is important to arrange instruments that will be used in learning activities.

The success of mathematical abilities enhancement and students' negative attitudes reduction towards Mathematics begins with the success of the researcher in making and analyzing instruments that will be given during the research takes place. The lack of consistency in prevailing mathematics anxiety theory is rectifiable by using modern measurement theory for measure construction (Sevindir et al., 2014). One way to do measurement is by questionnaires filled by a number of required samples. Questionnaires may be administered individually or in a group, and typically include a series of items reflecting the research aims (Ponto, 2015). A questionnaire is a tool that can be used in many measurements in any type of research. Questionnaires should always have a definite purpose that is related to the objectives of the research, and it needs to be clear from the outset how the findings will be used (Roopa \& Rani, 2012). The main indicator of measurement is the feasibility of its validity and reliability (Mohajan, 2017). In this case, the validity and reliability of an instrument are important. An instrument is said to be valid if the instruments are used to measure the corresponding object to be measured. The instrument is said to be reliable if the results are relatively similar even though it is used repeatedly (Ghofur et al., 2016). Validity and reliability can enhance transparency and reduce the bias possibility of qualitative research (Singh, 2014). Valid instruments indicate that it can be used to measure behavior that is meant to be measured (Haryeni \& Yendra, 2019). Instruments that have reliability can be used many times but produce similar data (Pramono et al., 2016). Instruments have a high reliability if the source of the error in the measurement can be minimized (Fiangga \& Sari, 2017).

Good quality instruments should be valid, reliable, standard, economical, and practical (Azwar, 2011). The instrument should be able to reveal particular facts and transformed them into data. Thus, the instrument that will be used should have good quality. Conversely, invalid, and unreliable examination results often failed to meet the purpose of examination and mislead decision making (Oluwatayo \& Fajobi, 2015). If the obtained data is not valid or is not appropriate with the facts, it might lead to the wrong conclusion (Arifin, 2017). The quality of research can be identified from the quality of arranged and developed instruments, in which it should be valid and reliable (Manongko, 2016). Other studies describe good instrument requirements as instruments that have high validity and reliability or meet psychometric requirements (Kartowagiran, 2018). An instrument has validity if the drawn conclusion is meaningful and inferences 
are valid based on the scores on the instrument (Creswell, 2009). Apart from the validity and reliability, an instrument also needs to meet the ability to measure samples in a large population and cost-effective (Rahman et al., 2019). Therefore, to support optimum research findings, before mathematics lesson implementation, the researcher has carefully analyzed the feasibility of instruments that have been developed. If the assumptions can be proven empirically, the instruments developed in a study have good predictive validity (Laliyo et al., 2019).

\section{Methods}

This research taken place from November 2018 to April 2019. Since this is developmental research, the method used in this study is Research and Development (R\&D). R\&D as a systematic process to develop, improve, and assess education programs and materials (Gall et al., 2010). This definition implies that research and development method in education is actually a process of developing research product, and eventually validate the product. All sixth-grade students in elementary schools in West Java were the population in this study. Participants included in the sample were 100 elementary school sixth-graders in Karawang Regency.

In this research, the product that will be developed and validated is learning materials, which are designed in such a way according to the CPA approach. The learning materials will then be used to measure the mathematical anxiety of elementary school students. There are three methods used in R\&D implementations which include descriptive, evaluative, and experiment (Sugiyono, 2016). In this study, the descriptive method is used to gather data that is required in arranging research instruments to measure the mathematical anxiety of elementary school students. The questionnaire given to students is in the form of a mathematical anxiety questionnaire using a Likert scale. Four responses can be chosen for each statement in the questionnaire which includes strongly agree (SA), agree (A), disagree (D), strongly disagree (SD). The mathematical anxiety instrument that is used is the modification of the mathematical anxiety instrument indicator developed by Cavanagh and Sparrow (2010), and it is combined with the learning using the CPA approach. As the next step, the evaluative method is used to evaluate the trial process of mathematical anxiety instrument development which is arranged according to the CPA approach to reduce the mathematical anxiety of elementary students. On the other hand, in this study, the experimental method is used to test the feasibility of research products by using instrument validity and reliability test. The product refers to the instrument that has been developed and run through the trial process using a quasi-experimental method. Obtained data is processed by using Microsoft Excel 2013 and SPSS Version 25. Microsoft Excel 2013 is used to calculate instrument validity, while SPSS version 25 is used to calculate instrument reliability using Cronbach's Alpha method. As the next step, the calculation result is analyzed based on a particular category. Validity value is interpreted based on the validity coefficient classification by Guilford (Putri, Isrokatun, et al., 2019) as shown in table 2. 
Table 2: Guilford's Validity Coefficient Classification

\begin{tabular}{|c|c|}
\hline $\mathbf{r}^{x y}$ value & Interpret \\
\hline $0,90<\mathrm{r}_{x y} \leq 1,00$ & Very high \\
\hline $0,70<\mathrm{r}^{x y} \leq 0,90$ & High \\
\hline $0,40<\mathrm{r}^{x y} \leq 0,70$ & Moderate (sufficient) \\
\hline $0,20<\mathrm{r}^{x y} \leq 0,40$ & Low \\
\hline $0,00<\mathrm{r}^{x y} \leq_{0,20}$ & Very low \\
\hline $\mathrm{r}^{x y} \leq_{0,00}$ & Not valid \\
\hline
\end{tabular}

Reliability value is interpreted based on Guilford's reliability classification (Putri, Isrokatun, et al., 2019) in table 3:

Table 3: Guilford's Reliability Coefficient Classification

\begin{tabular}{|c|c|}
\hline$r^{11}$ value & Interpretation \\
\hline$r^{11} \leq 0,20$ & Very low \\
\hline $0,20<r^{11} \leq 0,40$ & Low \\
\hline $0,40<r^{11} \leq 0,60$ & Intermediate \\
\hline $0,60<r^{11} \leq 0,80$ & High \\
\hline $0,80<r^{11} \leq 1,00$ & Very high \\
\hline
\end{tabular}

The research participant involved in this research is as much as 100 elementary school students throughout Purwakarta, Subang, and Karawang, West Java, Indonesia. The sampling was done through a purposive sampling technique. The selected sample should fulfill a particular requirement, in which samples must be a sixth-grader. Such sampling is done because the research will be implemented in grade 5 elementary school. Thus, the sample for instrument development should be those who have learned the topic. 100 participants were selected from three different areas. A greater number of samples will give more power and strength to the validation process (Lima-Rodríguez et al., 2015). The analysis technique used in this research is descriptive analysis in the form of a validity test and inferential analysis in the form of a reliability test using Cronbach's Alpha.

The development of students' mathematical anxiety instruments is carried out through several stages including, a preliminary study that is analyzing the definitions, factors, problems, and findings in mathematical anxiety of elementary school students through a literature review. The next stage of the instrument development is to analyze aspects, indicators, and items of mathematical anxiety based on the level of success in the form of a questionnaire blueprint. The last stage is the testing phase that is done by verifying the blueprint which is compiled to become a questionnaire. Lecturers of elementary school teacher education, and 
elementary school teachers whose focus on mathematics were asked to become expert assessors in determining the questionnaire feasibility and giving suggestions for its improvement. Then a readability test was conducted by asking some students randomly to fill in the questionnaire.

Several changes and improvements were taken by considering suggestions for experts and readability test results. Furthermore, empirical validation through validity and reliability tests were performed to ensure that it really can measure mathematical anxiety and can produce similar results even though being used repeatedly. As Wright et al (2019) said, the development of instruments was based on a process of theoretical review and empirical validation.

\section{Results}

The quality of mathematical anxiety instruments can be measured using validity and reliability test. The validity of an instrument indicates measurement results illustrating a particular aspect that is measured. On the other hand, reliability is related to the consistency of measurement. A reliable instrument provided a consistent measure of important characteristics despite background fluctuations. It reflects the true score-one that is free from random errors (Tsisiga et al., 2018). Therefore, it is undebatable that validity and reliability is a significant research instrument (Taherdoost, 2018). The first step is done before the instrument validity and reliability test was developing indicators into statement items in the questionnaire with regard to the literature review. As explained earlier, the indicator of the mathematical anxiety questionnaire in this research referred to (Cavanagh \& Sparrow, 2010) Table 1.

As seen in Table 1, three elements can influence the level of students' mathematical anxiety. Each element is further broken into three levels (low, medium, high). Based on Table 1, researchers developed the instrument by analyzing each element and identifying its indicators as the basis for developing a questionnaire item blueprint. It is in line with Sabri et al. (2019) who imply that to construct instruments with proper content validity it is necessary to do the following activities: (1) document analysis or pre-survey; (2) making the specification table (lattice); (3) consultation with experts (mentors); (4) writing the instrument. Each element and level have an indicator and become the basis for developing statement items that were used in the research. Those statements can be seen on the table of instrument blueprint (Table 4):

Table 4: Blueprint of Mathematical Anxiety Questionnaire Instrument

\begin{tabular}{|c|c|c|c|}
\hline Element & Indicator & Statement & Level \\
\hline \multirow[t]{2}{*}{ Attitudinal } & \multirow{2}{*}{$\begin{array}{l}\text { Fear of } \\
\text { what } \\
\text { he/she is } \\
\text { doing }\end{array}$} & $\begin{array}{l}\text { 1. I often skip school when there is } \\
\text { mathematics subject, especially when the } \\
\text { learning is about geometry that has a lot of } \\
\text { calculations. }\end{array}$ & High \\
\hline & & $\begin{array}{l}\text { 2. I always present in Mathematics subject } \\
\text { because in my opinion Mathematics is a } \\
\text { challenging subject, especially when }\end{array}$ & High \\
\hline
\end{tabular}




\begin{tabular}{|c|c|c|c|}
\hline & & $\begin{array}{llll}\text { discussing } & \text { geometry } & \text { with } & \text { many } \\
\text { calculations. }\end{array}$ & \\
\hline & & $\begin{array}{l}\text { 3. In every Math lesson, I prefer to sit at the } \\
\text { very back row, because the back seat is not } \\
\text { visible to the teacher so I am sure I will not } \\
\text { be appointed to come forward. }\end{array}$ & High \\
\hline & & $\begin{array}{l}\text { 4. I always want to sit in the front row so that } \\
\text { I can listen to the geometry material taught } \\
\text { by my teacher. }\end{array}$ & High \\
\hline & & $\begin{array}{l}\text { 5. I always ask my teacher, if there is } \\
\text { geometry material that I do not } \\
\text { understand. }\end{array}$ & High \\
\hline & \multirow{2}{*}{$\begin{array}{l}\text { Do not } \\
\text { want to do } \\
\text { something } \\
\text { that should } \\
\text { be done }\end{array}$} & $\begin{array}{l}\text { 6. I never answer questions about geometry, } \\
\text { which is difficult for me. }\end{array}$ & Medium \\
\hline & & $\begin{array}{l}\text { 7. No matter how difficult the question about } \\
\text { geometry is, I always try to do it. }\end{array}$ & Medium \\
\hline & \multirow{2}{*}{$\begin{array}{l}\text { The } \\
\text { expectatio } \\
\mathrm{n} \text { of } \\
\text { difficulties } \\
\text { in doing } \\
\text { something }\end{array}$} & $\begin{array}{l}\text { 8. Every time I get a question about } \\
\text { geometrical volume, it always difficult to } \\
\text { solve because there are many numbers } \\
\text { that I have to calculate. }\end{array}$ & Low \\
\hline & & $\begin{array}{l}\text { 9. I have no difficulty in doing questions } \\
\text { about geometrical volume because I } \\
\text { always careful in calculating the numbers. }\end{array}$ & Low \\
\hline \multirow{10}{*}{ Cognitive } & \multirow{4}{*}{$\begin{array}{l}\text { Worry to } \\
\text { be judged } \\
\text { by others } \\
\text { that } \\
\text { she/he } \\
\text { cannot do } \\
\text { things well }\end{array}$} & $\begin{array}{l}\text { 10. I always refuse every time the teacher } \\
\text { appoints me to go forward to answer } \\
\text { questions about geometry in front of the } \\
\text { class because I am afraid my friends will } \\
\text { laugh at me if my answer is wrong. }\end{array}$ & High \\
\hline & & $\begin{array}{l}\text { 11. I answered the question in front of the } \\
\text { class with confidence even though my } \\
\text { answer was wrong. By doing so, I came to } \\
\text { understand how to do it correctly. }\end{array}$ & High \\
\hline & & $\begin{array}{l}\text { 12. I always hide question papers from friends } \\
\text { and parents when the score is below } 70 \text {. }\end{array}$ & High \\
\hline & & $\begin{array}{l}\text { 13. I am aware of my failure in the previous } \\
\text { Mathematics test and I will try to get better } \\
\text { score in the future. }\end{array}$ & High \\
\hline & & $\begin{array}{l}\text { 14. When working on geometry test, I } \\
\text { remember another thing that, making the } \\
\text { time runs out. }\end{array}$ & Medium \\
\hline & & $\begin{array}{l}\text { 15. Mathematics is a difficult subject, so the } \\
\text { geometry formula is hard to remember. }\end{array}$ & Medium \\
\hline & $\begin{array}{l}\text { Empty } \\
\text { mind }\end{array}$ & $\begin{array}{l}\text { 16. I always remember the things that I have } \\
\text { to do even though the learning material is } \\
\text { difficult to understand. }\end{array}$ & Medium \\
\hline & & $\begin{array}{l}\text { 17. I cannot focus working on the geometry } \\
\text { problems that I do not understand. }\end{array}$ & Medium \\
\hline & & $\begin{array}{l}\text { 18. I always focus when working on all } \\
\text { questions about geometry. }\end{array}$ & Medium \\
\hline & & $\begin{array}{l}\text { 19. I am not sure with my answers to } \\
\text { geometry question. }\end{array}$ & Low \\
\hline
\end{tabular}




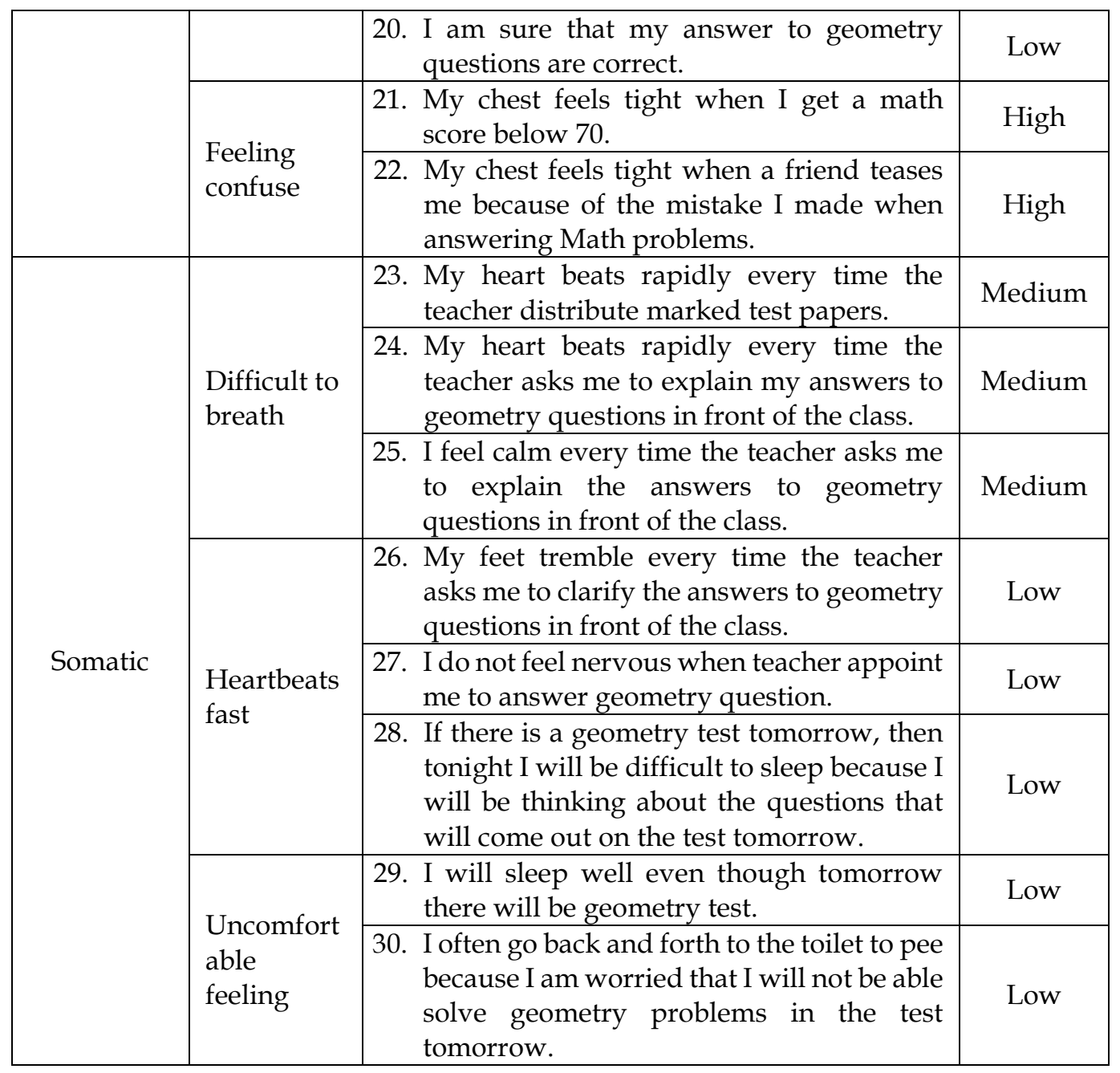

Statements that meet the requirements were further included in test trials. A sample of students' responses to the mathematical anxiety instrument developed in this study can be seen in Appendix 1 . Students' responses in the form of ordinal data were converted into nominal data. The ordinal data in question is a collection of student responses for each item. Further processes to determine the score described by Azwar (2010) are: 1) classify items according to their nature (favorable/unfavorable); 2) if the item is favorable, then SD response category is placed at the leftmost side and the SA response category is placed at the rightmost side; 3 ) classify the number of students according to their choice of responses. The frequency of students' response in each item should be the same; 4) Find the proportion value with $\mathrm{p}=\mathrm{f} / \mathrm{N}$ where $\mathrm{p}$ is proportion, $\mathrm{f}$ is frequency, and $\mathrm{N}$ is the number of respondents; 5) determine the pk score (cumulative proportion) that is the proportion in a category plus the proportion of all categories to the left; 6 ) determine Tpk score (Midpoint of cumulative proportion) by adding half proportion in the relevant category to the cumulative proportion in the category to the left. It can be formulated by Tpk $=1 / 2 p+p k b$ where Tpk is the midpoint of cumulative proportion, $\mathrm{p}$ is the proportion of its category, and $\mathrm{pkb}$ is the cumulative proportion in the category to the left; 7) determine $\mathrm{z}$ deviation value obtained by considering $z$ value for each Tpk. In this study, to determine the value for $\mathrm{z}$ normal deviation table can be used or use the formula '= NORMSINV 
(probability)' when using Microsoft Excel 2013 software. Probability in the formula can be filled with cells that show Tpk values; 8) shift the response category with the smallest value close to 0 (zero), i.e. make the price of $\mathrm{z}$ for the leftmost category equal to 0 . This is done to determine the price of $z+z$ and can be found by adding the absolute $z$ value at the most left category on all existing $z$ values so that $\mathrm{z}$ values in the other response categories will be positive. See table 5 and 6 for a more detailed scheme:

Table 5: The example of Mathematical Anxiety Scale Calculation for Positive Statement Item

\begin{tabular}{|c|c|c|c|c|c|c|c|c|}
\hline $\begin{array}{c}\text { Statemen } \\
\text { tItem }\end{array}$ & $\begin{array}{c}\text { Response } \\
\text { choices }\end{array}$ & $\mathbf{f}$ & $\mathbf{p}$ & $\mathbf{p k}$ & $\mathbf{T p k}$ & $\mathbf{Z}$ & $\mathbf{z +} \mathbf{z}^{*}$ & Rounding \\
\hline \multirow{4}{*}{2} & $\mathrm{SD}$ & 2 & 0.020 & 0.020 & 0.010 & -2.326 & 0.000 & 0 \\
\cline { 2 - 9 } & $\mathrm{D}$ & 2 & 0.020 & 0.040 & 0.030 & -1.881 & 0.445 & 0 \\
\cline { 2 - 9 } & $\mathrm{A}$ & 43 & 0.430 & 0.470 & 0.255 & -0.659 & 1.667 & 2 \\
\cline { 2 - 8 } & $\mathrm{SA}$ & 53 & 0.530 & 1.000 & 0.735 & 0.628 & 2.954 & 3 \\
\hline
\end{tabular}

Table 6: The example of Mathematical Anxiety Scale Calculation for Negative Statement

\begin{tabular}{|c|c|c|c|c|c|c|c|c|}
\hline $\begin{array}{c}\text { Statement } \\
\text { Item }\end{array}$ & $\begin{array}{c}\text { Response } \\
\text { choices }\end{array}$ & $\mathbf{f}$ & $\mathbf{p}$ & $\mathbf{p k}$ & $\mathbf{T p k}$ & $\mathbf{Z}$ & $\mathbf{z}+\mathbf{z}^{*}$ & Rounding \\
\hline \multirow{4}{*}{30} & $\mathrm{SD}$ & 5 & 0.050 & 0.050 & 0.025 & -1.960 & 0.000 & 0 \\
\cline { 2 - 9 } & $\mathrm{D}$ & 11 & 0.110 & 0.160 & 0.105 & -1.254 & 0.706 & 1 \\
\cline { 2 - 9 } & $\mathrm{A}$ & 51 & 0.510 & 0.670 & 0.415 & -0.215 & 1.745 & 2 \\
\cline { 2 - 8 } & $\mathrm{SA}$ & 33 & 0.330 & 1.000 & 0.835 & 0.974 & 2.934 & 3 \\
\hline
\end{tabular}

Table 5 clearly illustrates that item number 2 of mathematical anxiety questionnaire has a positives scale and the score to be used can be seen in the rounding columns for SD, D, A, and SA categories. Those are 0, 0, 2, and 3 respectively. Meanwhile, Table 6 shows a mathematical anxiety scale questionnaire for negative items which is represented by item statement number 30. The score to be used can be seen in the rounding column as much as $0,1,2$, and 3 for SA, A, D, and SD respectively. The data obtained is used for calculating the validity and reliability of students' mathematical anxiety scale instruments. Once the student answers collected, we convert them into nominal figures.

\subsection{Validity Test Analysis}

After mathematical anxiety instruments constructed, sixth-grade elementary school students filled it in for trial. Results obtained from the trial are further be used in the validity test. Table 7 presents the validity test results. 
Table 7: Recapitulation of Validity Test Results for Mathematical Anxiety Instrument

\begin{tabular}{|c|c|c|c|c|c|}
\hline $\begin{array}{c}\text { Correlation } \\
\text { between }\end{array}$ & $\begin{array}{c}\text { Correlation } \\
\text { Value (r) }\end{array}$ & $\begin{array}{c}\text { r value } \\
\text { count }\end{array}$ & $\begin{array}{c}r_{\text {table }} \text { value } \\
(k=n-2, \alpha=5 \%)\end{array}$ & Note & Conclusion \\
\hline $\begin{array}{l}\text { Number } 1 \\
\text { with Total }\end{array}$ & 0,57 & 6,81 & 0,198 & $\begin{array}{l}\mathrm{r} \text { positive, } \\
\mathrm{r}_{\text {count }}>\mathrm{r}_{\text {table }}\end{array}$ & Valid \\
\hline $\begin{array}{l}\text { Number } 2 \\
\text { with Total }\end{array}$ & 0,52 & 6,07 & 0,198 & $\begin{array}{l}\mathrm{r} \text { positive, } \\
\mathrm{r}_{\text {count }}>\mathrm{r}_{\text {table }}\end{array}$ & Valid \\
\hline $\begin{array}{l}\text { Number } 3 \\
\text { with Total }\end{array}$ & 0,43 & 4,65 & 0,198 & $\begin{array}{l}\mathrm{r} \text { positive, } \\
\mathrm{r}_{\text {count }}>\mathrm{r}_{\text {table }}\end{array}$ & Valid \\
\hline $\begin{array}{l}\text { Number } 4 \\
\text { with Total }\end{array}$ & 0,31 & 3,25 & 0,198 & $\begin{array}{l}\mathrm{r}_{\text {p positive, }} \\
\mathrm{r}_{\text {count }}<\mathrm{r}_{\text {table }}\end{array}$ & Valid \\
\hline $\begin{array}{l}\text { Number } 5 \\
\text { with Total }\end{array}$ & 0,29 & 3,03 & 0,198 & $\begin{array}{c}\text { positive, } \\
\mathrm{r}_{\text {count }}<\mathrm{r}_{\text {table }}\end{array}$ & Valid \\
\hline $\begin{array}{l}\text { Number } 6 \\
\text { with Total }\end{array}$ & 0,46 & 5,11 & 0,198 & $\begin{array}{l}\mathrm{r} \text { positive, } \\
\mathrm{r}_{\text {count }}>\mathrm{r}_{\text {table }}\end{array}$ & Valid \\
\hline $\begin{array}{l}\text { Number } 7 \\
\text { with Total }\end{array}$ & 0,52 & 6,03 & 0,198 & $\begin{array}{l}\text { r positive, } \\
r_{\text {count }}>r_{\text {table }}\end{array}$ & Valid \\
\hline $\begin{array}{l}\text { Number } 8 \\
\text { with Total }\end{array}$ & 0,50 & 5,73 & 0,198 & $\begin{array}{l}\mathrm{r} \text { positive, } \\
\mathrm{r}_{\text {count }}>\mathrm{r}_{\text {table }}\end{array}$ & Valid \\
\hline $\begin{array}{l}\text { Number } 9 \\
\text { with Total }\end{array}$ & 0,60 & 7,38 & 0,198 & $\begin{array}{l}\mathrm{r} \text { positive, } \\
\mathrm{r}_{\text {count }}>\mathrm{r}_{\text {table }}\end{array}$ & Valid \\
\hline $\begin{array}{l}\text { Number } 10 \\
\text { with Total }\end{array}$ & 0,58 & 7,02 & 0,198 & $\begin{array}{l}\text { r positive, } \\
r_{\text {count }}>r_{\text {table }}\end{array}$ & Valid \\
\hline $\begin{array}{l}\text { Number } 11 \\
\text { with Total }\end{array}$ & 0,64 & 8,31 & 0,198 & $\begin{array}{l}\mathrm{r}_{\text {p positive }} \\
\mathrm{r}_{\text {count }}>\mathrm{r}_{\text {table }}\end{array}$ & Valid \\
\hline $\begin{array}{l}\text { Number } 12 \\
\text { with Total }\end{array}$ & 0,48 & 5,45 & 0,198 & $\begin{array}{l}\text { r positive, } \\
r_{\text {count }}>r_{\text {table }}\end{array}$ & Valid \\
\hline $\begin{array}{c}\text { Number } 13 \\
\text { with Total }\end{array}$ & 0,48 & 5,36 & 0,198 & $\begin{array}{l}\mathrm{r} \text { positive, } \\
\mathrm{r}_{\text {count }}>\mathrm{r}_{\text {table }}\end{array}$ & Valid \\
\hline $\begin{array}{l}\text { Number } 14 \\
\text { with Total }\end{array}$ & 0,39 & 4,15 & 0,198 & $\begin{array}{c}\text { positive, } \\
\mathrm{r}_{\text {count }}<\mathrm{r}_{\text {table }}\end{array}$ & Valid \\
\hline $\begin{array}{l}\text { Number } 15 \\
\text { with Total }\end{array}$ & 0,48 & 5,35 & 0,198 & $\begin{array}{l}\mathrm{r} \text { positive, } \\
\mathrm{r}_{\text {count }}>\mathrm{r}_{\text {table }}\end{array}$ & Valid \\
\hline $\begin{array}{l}\text { Number } 16 \\
\text { with Total }\end{array}$ & 0,48 & 5,37 & 0,198 & $\begin{array}{l}\mathrm{r} \text { positive, } \\
\mathrm{r}_{\text {count }}>\mathrm{r}_{\text {table }}\end{array}$ & Valid \\
\hline $\begin{array}{l}\text { Number } 17 \\
\text { with Total }\end{array}$ & 0,42 & 4,60 & 0,198 & $\begin{array}{l}\mathrm{r} \text { positive, } \\
\mathrm{r}_{\text {count }}>\mathrm{r}_{\text {table }}\end{array}$ & Valid \\
\hline $\begin{array}{l}\text { Number } 18 \\
\text { with Total }\end{array}$ & 0,56 & 6,62 & 0,198 & $\begin{array}{l}\mathrm{r}_{\text {p positive, }} \\
\mathrm{r}_{\text {count }}>\mathrm{r}_{\text {table }}\end{array}$ & Valid \\
\hline $\begin{array}{l}\text { Number } 19 \\
\text { with Total }\end{array}$ & 0,41 & 4,50 & 0,198 & $\begin{array}{l}\text { r positive, } \\
r_{\text {count }}>r_{\text {table }}\end{array}$ & Valid \\
\hline $\begin{array}{l}\text { Number } 20 \\
\text { with Total }\end{array}$ & 0,46 & 5,08 & 0,198 & $\begin{array}{l}\text { r positive, } \\
r_{\text {count }}>r_{\text {table }}\end{array}$ & Valid \\
\hline $\begin{array}{c}\text { Number } 21 \\
\text { with Total }\end{array}$ & 0,31 & 3,25 & 0,198 & $\begin{array}{c}\text { positive, } \\
\mathrm{r}_{\text {count }}<\mathrm{r}_{\text {table }}\end{array}$ & Valid \\
\hline $\begin{array}{l}\text { Number } 22 \\
\text { with Total }\end{array}$ & 0,37 & 3,90 & 0,198 & $\begin{array}{c}\text { positive, } \\
\mathrm{r}_{\text {count }}<\mathrm{r}_{\text {table }}\end{array}$ & Valid \\
\hline $\begin{array}{l}\text { Number } 23 \\
\text { with Total }\end{array}$ & 0,44 & 4,85 & 0,198 & $\begin{array}{l}\text { r positive, } \\
r_{\text {count }}>r_{\text {table }}\end{array}$ & Valid \\
\hline
\end{tabular}




\begin{tabular}{|c|c|c|c|c|c|}
\hline $\begin{array}{c}\text { Number 24 } \\
\text { with Total }\end{array}$ & 0,53 & 6,15 & 0,198 & $\begin{array}{c}\mathrm{r}_{\text {positive, }} \\
\mathrm{r}_{\text {count }}>\mathrm{r}_{\text {table }}\end{array}$ & Valid \\
\hline $\begin{array}{c}\text { Number 25 } \\
\text { with Total }\end{array}$ & 0,63 & 7,94 & 0,198 & $\begin{array}{c}\mathrm{r}_{\text {positive, }} \\
\mathrm{r}_{\text {count }}>\mathrm{r}_{\text {table }}\end{array}$ & Valid \\
\hline $\begin{array}{c}\text { Number 26 } \\
\text { with Total }\end{array}$ & 0,56 & 6,74 & 0,198 & $\begin{array}{c}\mathrm{r} \text { positive, } \\
\mathrm{r}_{\text {count }}>\mathrm{r}_{\text {table }}\end{array}$ & Valid \\
\hline $\begin{array}{c}\text { Number 27 } \\
\text { with Total }\end{array}$ & 0,22 & 2,25 & 0,198 & $\begin{array}{c}\text { positive, } \\
\mathrm{r}_{\text {count }}<\mathrm{r}_{\text {table }}\end{array}$ & Valid \\
\hline $\begin{array}{c}\text { Number 28 } \\
\text { with Total }\end{array}$ & 0,52 & 6,05 & 0,198 & $\begin{array}{c}\mathrm{r} \text { positive, } \\
\mathrm{r}_{\text {count }}>\mathrm{r}_{\text {table }}\end{array}$ & Valid \\
\hline $\begin{array}{c}\text { Number 29 } \\
\text { with Total }\end{array}$ & 0,32 & 3,35 & 0,198 & $\begin{array}{c}\text { positive, } \\
\mathrm{r}_{\text {count }}<\mathrm{r}_{\text {table }}\end{array}$ & Valid \\
\hline $\begin{array}{c}\text { Number 30 } \\
\text { with Total }\end{array}$ & 0,57 & 6,87 & 0,198 & $\begin{array}{c}\mathrm{r}_{\text {positive, }} \\
\mathrm{r}_{\text {count }}>\mathrm{r}_{\text {table }}\end{array}$ & Valid \\
\hline
\end{tabular}

Table 7 indicates 23 items that have valid values. While items number 4, 5, 14, 21, 22,27 , and 29 show weak correlation value. The item is valid if the correlation value is at least in the medium category based on the comparison of $r$ count and $r$ tables. According to Guilford correlation value categories, the value of $r_{\text {count }}>r_{\text {table }}$ of the 23 items is classified as moderate. Therefore these 23 items were further included in the mathematical anxiety instruments.

\subsection{Reliability Test Analysis}

Aside from the validity test resulting in 23 valid items, reliability tests were performed as well. The test used Cronbach's Alpha calculation using SPSS type 25 software. The selection of Cronbach's alpha as a measure of instrument reliability for mathematical anxiety instruments is because Cronbach's Alpha can test a questionnaire-type instrument that has more than one answer. As Yusup (2018) suggests, Cronbach's Alpha test is suitable for instruments in the form of essays or questionnaires. Table 8 presents the reliability of mathematics anxiety instruments.

Table 8: Test Results of Mathematical Anxiety Reliability Instruments

\begin{tabular}{|c|c|c|}
\hline $\begin{array}{c}\text { Cronbach's } \\
\text { Alpha }\end{array}$ & Cronbach's Alpha Based on Standardized Items & $\begin{array}{c}\text { No of } \\
\text { Items }\end{array}$ \\
\hline 0,874 & 0,877 & 30 \\
\hline
\end{tabular}

From the reliability test results as illustrated in the table 8, Cronbach's Alpha values for the instrument are 0.874 . This number implies that instrument reliability is high. Thus, this student mathematical anxiety instrument is considered consistent to be used many times in further research.

\section{Discussion}

Research using questionnaire as its instrument require validity and reliability insurance before collecting data from participants. Validity and reliability are key indicators of measuring instrument quality (Kimberlin \& Winterstein, 2008). The validity test implies that there are 23 valid items with the lowest $r_{x y}$ value is 0.29 and the highest is 0.64 . It has been suggested that correlation coefficients below 0.3 should be considered as low, 0.3 to less than 0.5 as moderate, while 0.5 and 
above as a high (Tsang et al., 2017). We can look at some information in Table 7 that 13 items have high correlation value. This shows that $43,33 \%$ or almost half of all items in the questionnaire is sure can be used. In particular, we should stop considering moderate correlations as evidence of reliability or validity (Post, 2016). Even for purposes of applied decision making, reliance on criterion validity or content coverage is not enough (Taherdoost, 2018). If pulled back into the validity classification table (Lodico et al., 2006), these figures indicate the level of validity is in the position of low to medium. The validity coefficient values range from 1.00 to -1.00 . The coefficient value of 1.00 indicates that individual test items and test criteria have relatively the same results. Whereas zero validity coefficient indicates that there is no relationship between the instrument and its criteria.

Generally, a higher validity coefficient indicates the higher validity of the instrument (Buchan et al., 2005). However, the basis for decision making on the validity test can also be determined through $r_{\text {count }}$ and $r_{\text {table. }}$ If $r_{\text {count }}$ is greater than $r_{\text {table, }}$ then the instrument can be declared significant and valid (Mahendra, 2015). Furthermore, the reliability test is a continuation of the validity test, where the items included in the test are only valid ones (Fridayanthie, 2016). The reliability test using Cronbach's Alpha calculation results showed the reliability value of the mathematics anxiety instrument was 0.874 . as it is analyzed through the reliability classification proposed by Guilford (Suherman, 2003), it is found that this value classified as high reliability. Cronbach's alpha of at least 0.70 has been suggested to indicate adequate internal consistency and could be considered acceptable reliability (Bolarinwa, 2015; Lima-Rodríguez et al., 2015; Tsang et al., 2017). A rule of thumb that $\alpha=0.7$ indicates acceptable, and $\alpha=0.8$ represents good reliability (Wells et al., 2011). In conducting research, aside from performing proper data collection, ensuring that the instrument can function correctly is also essential (Dikko, 2016). In this case, the instrument can work properly only if the instrument is valid and reliable. As an example, a study performed an instrument trial in seventh-grade students, resulting in correlations between the two items ranged from 0.46 to 0.60 . Cronbach's alpha for this scale ranged from 0.63 to 0.75 , indicating acceptable internal reliability (Wang et al., 2020). Whereas if the value of instrument correlation is less than 0.40 like the seven items found in Table 7, then it is considered invalid because the correlation is weak. High or strong correlation means that two or more variables have strong validity with each other, while low correlation means that the variable is almost unrelated or invalid (Dalvi \& Kant, 2018).

\section{Conclusion}

Research to develop Mathematical Anxiety instruments for elementary school students is carried out comprehensively. This study involved 100 elementary school students in Indonesia. Mathematical anxiety instruments have been created and arranged based on instrument modification (Cavanagh \& Sparrow, 2010). The results showed there were seven invalid items due to weak correlation. Therefore, these items considered unable to measure students' mathematical anxiety. Meanwhile, the other 23 of the 30 items are valid and reliable. Hence, we claim that these 23 items are proper to use in measuring the mathematical anxiety of elementary school students. Mathematical anxiety instrument developed 
through this research is expected to give contributions to teachers, parents and even researchers to solve mathematical anxiety problems experienced by elementary school students as early as possible. To conclude, mathematics anxiety items developed through this study can be used as a questionnaire-type instrument for future research.

\section{Limitation}

Students assume mathematics as the learning that is difficult to understand and always requires high attention. This condition leads to students' fear and anxiety in learning mathematics. It is necessary to measure elementary school students' mathematical anxiety so that teachers can design meaningful learning approaches/strategies to generate students' interest in learning and reduce students' anxiety when learning mathematics. It is expected that when students are not anxious in learning, students are more motivated to learn, which leads to better mathematical learning achievement. Teachers and researchers should avoid ambiguous statements in the questionnaire to obtain a valid and reliable instrument.

\section{Acknowledgments}

This work is supported by Research, Partnerships, and Business, as well as the management of the Research and Community Service Institute (LPPM) of Universitas Pendidikan Indonesia (UPI) who provide opportunities for authors toresearch mathematical anxiety instruments development, especially to measure mathematical anxiety of elementary school students. We would also like to thank students and teachers who made this study possible.

\section{References}

Afrianti, N. F., \& Prabawanto, S. (2020). On surveying of fifth grade mathematical anxiety in term of gender. Journal of Physics: Conference Series, 1521(3). https://doi.org/10.1088/1742-6596/1521/3/032079

Alves, M., Rodrigues, C. S., Rocha, A. M. A. C., \& Coutinho, C. (2016). Self-efficacy, mathematics' anxiety and perceived importance: an empirical study with Portuguese engineering students. European Journal of Engineering Education, 41(1), 105-121. https:/ / doi.org/10.1080/03043797.2015.1095159

Annisa, D. F., \& Ifdil, I. (2016). Konsep Kecemasan (Anxiety) pada Lanjut Usia (Lansia) [The concept of Anxiety (Anxiety) in the Elderly (Elderly)]. Konselor, 5(2), 28-36. https:// doi.org/10.24036/02016526480-0-00

Aosi, G., Metrianis, \& Rifma. (2019). STEM Based Learning to Overcome Math Anxiety. Journal of Physics: Conference Series, 1387(1). https://doi.org/10.1088/17426596/1387/1/012053

Ardi, Z., Rangka, I. B., Ifdil, I., Suranata, K., Azhar, Z., Daharnis, D., Afdal, A., \& Alizamar, A. (2019). Exploring the elementary students learning difficulties risks on mathematics based on students mathematic anxiety, mathematics self-efficacy and value beliefs using rasch measurement. Journal of Physics: Conference Series, 1157(3). https://doi.org/10.1088/1742-6596/1157/3/032095

Arifin, Z. (2017). Kriteria Instrumen dalam Suatu Penelitian [Instrument Criteria in a Research]. Jurnal Theorems (The Original Research of Mathematics), 2(1), 28-36. http://dx.doi.org/10.31949/th.v2i1.571

Ashcraft, M. H., \& Moore, A. M. (2009). Mathematics Anxiety and the Affective Drop in 
Performance. Journal of Psychoeducational Assessment, 27(3), 197-205. https:// doi.org/10.1177/0734282908330580

Azwar, S. (2010). Sikap Manusia Teori dan Pengukurannya [The Human Attitude Theory and Its Measurement]. Pustaka Pelajar.

Azwar, S. (2011). Reliabilitas dan Validitas [Reliability and Validity]. Pustaka Pelajar.

Bolarinwa, O. A. (2015). Principles and Methods of Validity and Reliability Testing of Questionnaires Used in Social and Health Science Researches. Niger Postgrad Med, 22, 195-201.

Buchan, B. D., DeAngelis, D. L., \& Levinson, E. M. (2005). A comparison of the web-based and paper-and-pencil versions of the career key interest inventory with a sample of university women. Journal of Employment Counseling, 42(1), 39-46. https://doi.org/10.1002/j.2161-1920.2005.tb00897.x

Cavanagh, R., \& Sparrow, L. (2010). Measuring mathematics anxiety: Developing a construct model. Paper Presented at The AARE Annual Conference, Melbourne 2010, 1-11. Retrieved from https://www.aare.edu.au/publications/aare-conferencepapers/show/6015/measuring-mathematics-anxiety-paper-1-developing-aconstruct-model

Creswell, J. W. (2009). Research design: Qualitative, quantitative, and mixed methods approaches (Third). Sage Publication, Inc.

Cropp, I. (2017). Using peer mentoring to reduce mathematical anxiety. Research Papers in Education, 32(4), 481-500. https://doi.org/10.1080/02671522.2017.1318808

Dalvi, M. V., \& Kant, R. (2018). Effect of supplier development activities on performance outcomes: an empirical study. Benchmarking: An International Journal, 25(2), 489516. https://doi.org/10.1108/BIJ-07-2016-0107

Dikko, M. (2016). Establishing Construct Validity and Reliability: Pilot Testing of a Qualitative Interview for Research in Takaful (Islamic Insurance). Qualitative Report, 21(3), 521-528.

Fiangga, S., \& Sari, Y. M. (2017). Analisis Generalisabilitas Multi Faset pada Instrumen Penalaran Matematika SMP [Multi-facet Generalization Analysis on Junior High School Math Reasoning Instruments]. Jurnal Elemen, 3(2), 118. https://doi.org/10.29408/jel.v3i2.398

Fridayanthie, E. W. (2016). Analisa Sistem Informasi Upload Promosi Harga Menggunakan SAP terhadap Kepuasan Pengguna Pada PT Hero Supermarket Tbk [Upload Price Promotion Information System Analysis Using SAP on User Satisfaction at PT Hero Supermarket Tbk]. Jurnal Khatulistiwa Informatika, 4(1), 30 43. https://doi.org/10.31294/jki.v4i1.1255

Gall, M. D., Gall, J. P., \& Borg, W. R. (2010). Applying Educational Research. Pearson Education, Inc.

Ghofur, A., Dageng, I. N. S., Widiati, U., \& Setyosari, P. (2016). Designing the Reliable and Valid Assessment's Instrument for English Speaking Skill. The 7Th International Conference on Educational Technology of Adi Buana, 34-43. https://doi.org/10.31227/osf.io/8h2av

Haryeni, \& Yendra, N. (2019). Impact of Service Quality Dimensions on Patient Satisfaction and Repurchase Intentions in the Public Health Industry. Third International Conference On Economics Education, Economics, Business and Management, Accounting and Entrepreneurship (PICEEBA 2019), 97, 456-465. https://doi.org/10.2991/piceeba-19.2019.52

Hendriana, H. (2012). Pembelajaran Matematika Humanis Dengan Metaphorical Thinking Untuk Meningkatkan Kepercayaan Diri Siswa [Humanist Mathematics Learning With Metaphorical Thinking To Increase Student Self Confidence]. Infinity Journal, 1(1), 90. https:// doi.org/10.22460/infinity.v1i1.9 
Kartowagiran, B. (2018). Optimalisasi Uji Tingkat Kompetensi Di SMK untuk Meningkatkan Soft Skill Lulusan [Optimization of Competency Level Test in Vocational Schools to Increase Soft Skill of Graduates]. Jurnal Dinamika Vokasional Teknik Mesin, 3(2013), 101-109. https:/ / doi.org/10.21831/dinamika.v3i2.21406

Kimberlin, C. L., \& Winterstein, A. G. (2008). Validity and reliability of measurement instruments used in research. American Journal of Health-System Pharmacy, 65(23), 2276-2284. https://doi.org/10.2146/ajhp070364

Kristanti, R., \& Widyawati, Y. (2009). Tingkat Kecemasan Matematika (Perbedaan Antara Siswa Yang Belajar Dengan Rote Learning dan Inquiry Learning) [Mathematical Anxiety Level (Difference Between Students Learning With Rote Learning and Inquiry Learning)]. World of Computing, Articles on Artificial Intelligence, 47-58.

Laliyo, L. A. R., Botutihe, D. N., \& Panigoro, C. (2019). The development of two-tier instrument based on distractor to assess conceptual understanding level and student misconceptions in explaining redox reactions. International Journal of Learning, Teaching and Educational Research, 18(9), 216-237. https://doi.org/10.26803/ijlter.18.9.12

Levere, K. M., \& Kahlon, P. K. (2019). Investigating mathematics anxiety over time in university engineering students. International Journal of Learning, Teaching and Educational Research, 18(7), 51-69. https:/ / doi.org/10.26803/ijlter.18.7.4

Lima-Rodríguez, J. S., Lima-Serrano, M., \& Domínguez-Sánchez, I. (2015). Psychometric properties of an instrument to measure family disease management. International Journal of Clinical and Health Psychology, 15(3), 253-264. https://doi.org/10.1016/j.ijchp.2015.05.002

Lodico, M. G., Spaulding, D. T., \& Voegtle, K. H. (2006). Methods in Educational Research from Theory to Practice. Jossey-Bass. https:/ / doi.org/10.1177/001312457500700301

Mahendra, I. (2015). Analisa Penerimaan Pengguna Sistem Informasi Koperasi pada Koperasi Karyawan Budi Setia Jakarta dengan Technology Acceptance Model [Analysis of Cooperative Information System User Acceptance at the Budi Setia Jakarta Employee Cooperative with the Technology Acceptance Model]. Jurnal Pilar Nusa Mandiri, 11(1), 70-80. Retrieved from http:/ / ejournal.nusamandiri.ac.id/index.php/pilar/article/view/415

Manongko, A. A. C. (2016). The Preparation and Testing of Instruments Research on Factors Affecting the Productivity of Household Farmer. IOSR Journal of Business and Management (IOSR-JBM), 18(9), 61-73.

Mizala, A., Martínez, F., \& Martínez, S. (2015). Pre-service elementary school teachers' expectations about student performance: How their beliefs are affected by their mathematics anxiety and student's gender. Teaching and Teacher Education, 50, 7078. https://doi.org/10.1016/j.tate.2015.04.006

Mohajan, H. K. (2017). Two Criteria For Good Measurements in Research: Validity and Reliability. Annals of Spiru Haret University. Economic Series, 59-82.

National Research Council. (2001). Adding It Up. In J. Kilpatrick, J. Swafford, \& B. Findell (Eds.). National Academy Press. Retrieved from http://www.wakamonoup.jp/top/pdf/Third-party_evaluation_2013_points.pdf

Oluwatayo, J. A., \& Fajobi, O. O. (2015). Validity of Post-Unified Tertiary Matriculation Examination (POST-UTME) as Screening Instrument for Selecting Candidates into Degree Programmes in Nigerian Universities. International Journal of Learning, Teaching and Educational Research, 13(1), 94-101.

Papadakis, S., Kalogiannakis, M., \& Zaranis, N. (2017). Improving Mathematics Teaching in Kindergarten with Realistic Mathematical Education. Early Childhood Education Journal, 45(3), 369-378. https:/ / doi.org/10.1007/s10643-015-0768-4

Papadakis, S., Kalogiannakis, M., \& Zaranis, N. (2018). The effectiveness of computer and 
tablet assisted intervention in early childhood students' understanding of numbers. An empirical study conducted in Greece. Education and Information Technologies, 23(5), 1849-1871. https://doi.org/10.1007/s10639-018-9693-7

Ponto, J. (2015). Understanding and Evaluating Survey Research. Journal of the Advanced Practitioner in Oncology, 6(2), 168-171. Retrieved from https:// pubmed.ncbi.nlm.nih.gov/26649250

Post, M. W. (2016). What to Do With "Moderate" Reliability and Validity Coefficients? Archives of Physical Medicine and Rehabilitation, 97(7), 1051-1052. https://doi.org/10.1016/j.apmr.2016.04.001

Pramono, K. F., Muluk, C., \& Nazaruddin. (2016). Pengaruh Distribusi FisikTerhadap Penjualan Pupuk NPK Merek Mahkota (Studi Kasus: PT Sentana Adidaya Pratama [Effect of Physical Distribution on Sales of Mahkota NPK Fertilizer (Case Study: PT Sentana Adidaya Pratama)]. Al-Irsyad: Jurnal Pendidikan Dan Konseling, 6(2), 139-148. Retrieved from http://jurnal.uinsu.ac.id/index.php/alirsyad/article/view/6624

Putri, H. E., Isrokatun, I., Majid, N. W. A., \& Ridwan, T. (2019). Spatial sense instrument for prospective elementary school student. Journal of Physics: Conference Series, 1318(1). https://doi.org/10.1088/1742-6596/1318/1/012142

Putri, H. E., Muqodas, I., Wahyudy, M. A., \& Nuraeni, F. (2019). The Effect of ConcretePictorial-Abstract ( CPA ) Approach on The Decrease of Mathematical Anxiety in Primary School. Proceedings of The 2nd International Conference on Elementary Education, 2, 80-93. Retrieved from http:// proceedings.upi.edu/index.php/icee/article/view/609

Rahman, Z. A., Mohamed, M., Ismail, M. I., \& Arujunan, R. (2019). Digital Version for Obesity Predictor Instrument Among Adolescents. International Journal of Academic Research in Business and Social Sciences, 9(13), 96-106. https://doi.org/10.6007/ijarbss/v9-i13/6246

Ramirez, G., Chang, H., Maloney, E. A., Levine, S. C., \& Beilock, S. L. (2016). On the relationship between math anxiety and math achievement in early elementary school: The role of problem solving strategies. Journal of Experimental Child Psychology, 141, 83-100. https://doi.org/10.1016/j.jecp.2015.07.014

Roopa, S., \& Rani, M. (2012). Questionnaire Designing for a Survey. The Journal of Indian Orthodontic Society, 46(4), 273-277. https://doi.org/10.5005/jp-journals-100211104

Sabri, T., Kurniadi, I., \& Soeharto, S. (2019). Development of Interactive Teaching Materials Using Whiteboard Animation for Civic Learning in Elementary School. EDUCATIO: Journal Of Education, 4(2), 125-139.

Sevindir, H. K., Yazici, C., \& Yazici, V. (2014). Mathematics Anxiety of Secondary School Students: A Case Study for Kocaeli Area. Procedia - Social and Behavioral Sciences, 152, 630-636. https://doi.org/10.1016/j.sbspro.2014.09.254

Shishigu, A. (2018). Mathematics Anxiety and Prevention Strategy: An Attempt to Support Students and Strengthen Mathematics Education. Mathematics Education Trends and Research, 2018(1), 1-11. https://doi.org/10.5899/2018/metr-00096

Singh, A. S. (2014). Conducting case study research in non-profit organisations. Qualitative Market Research, 17(1), 77-84. https:// doi.org/10.1108/QMR-04-2013-0024

Sofiatun, S., Deniyanti, P., \& El, L. (2018). The effect of scaffolding techniques on the ability of student's reasoning ability and mathematics anxiety reviewed from gender. Unnes Journal of Mathematics Education, 7(1), 63-71. https://doi.org/10.15294/ujme.v7i1.22574

Suarjana, I. M., Nanci Riastini, N. P., \& Yudha Pustika, I. G. N. (2017). Penerapan Pendekatan Kontekstual Berbantuan Media Konkret Untuk Meningkatkan 
Aktivitas Dan Hasil Belajar [Effect of Physical Distribution on Sales of Mahkota NPK Fertilizer (Case Study: PT Sentana Adidaya Pratama)]. International Journal of Elementary Education, 1(2), 103. https://doi.org/10.23887/ijee.v1i2.11601

Sugiyono. (2016). Metode Penelitian Kuantitatif, Kualitatif dan RED [Quantitative, Qualitative, and RED Research Methods]. Alfabeta.

Suherman, E. (2003). Evaluasi Pembelajaran Matematika [Evaluation of Mathematics Learning]. JICA UPI Bandung.

Sunardi, Yudianto, E., Susanto, Kurniati, D., Cahyo, R. D., \& Subanji. (2019). Anxiety of students in visualization, analysis, and informal deduction levels to solve geometry problems. International Journal of Learning, Teaching and Educational Research, 18(4), 171-185. https:// doi.org/10.26803/ijlter.18.4.10

Taherdoost, H. (2018). Validity and Reliability of the Research Instrument; How to Test the Validation of a Questionnaire/Survey in a Research. SSRN Electronic Journal, 5(3), 28-36. https://doi.org/10.2139/ssrn.3205040

TIMSS \& PIRLS Study Center. (2016). TIMSS and PIRLS. Retrieved from http://timss2015.org/

Tobias, S., \& Weissbrod, C. (1980). Anxiety and Mathematics: An Update. Harvard $\begin{array}{lrr}\text { Educational Review, } & \text { 50(1), } \\ \text { https://doi.org/10.17763/haer.50.1.xw483257j6035084 }\end{array}$

63-70.

Tsang, S., Royse, C. F., \& Terkawi, A. S. (2017). Guidelines for developing, translating, and validating a questionnaire in perioperative and pain medicine. Saudi Journal of Anaesthesia, 11(Suppl 1), 80-89. https://doi.org/10.4103/sja.SJA_203_17

Tsisiga, M. J., Odebero, S. O., \& Ndiku, J. M. (2018). Analysis of Trends in Enrolment Rates and Subsidized School Funding in Kenyan Public Secondary Schools. Scholars Journal of Arts, Humanities and Social Sciences, 6(7), 1465-1476. https://doi.org/10.21276/sjahss.2018.6.7.17

Wang, Z., Oh, W., Malanchini, M., \& Borriello, G. A. (2020). The developmental trajectories of mathematics anxiety: Cognitive, personality, and environmental correlates. Contemporary Educational Psychology, 61, 101876. https://doi.org/10.1016/j.cedpsych.2020.101876

Wells, G. A., Russell, A. S., Haraoi, B., Bissonnette, R., \& Ware, C. F. (2011). Validity of Quality of Life Measurement Tools - From Generic to Disease-specific. The Journal of Rheumatology, 88, 2-6. https://doi.org/10.3899/jrheum.110906

Wright, K. L., Hodges, T. S., \& McTigue, E. M. (2019). A validation program for the SelfBeliefs, Writing-Beliefs, and Attitude Survey: A measure of adolescents' motivation toward writing. Assessing Writing, 39, 64-78. https:// doi.org/10.1016/j.asw.2018.12.004

Yuliyanto, A., Turmudi, T., Agustin, M., Putri, H. E., \& Muqodas, I. (2019). The Interaction Between Concrete-Pictorial-Abstract (CPA) Approach and Elementary Students' Self-Efficacy In Learning Mathematics. Al Ibtida: Jurnal Pendidikan Guru MI, 6(2), 244-255. https://doi.org/10.24235/al.ibtida.snj.v6i2.5226

Yusup, F. (2018). Uji Validitas dan Reliabilitas Instrumen Penelitian Kuantitatif [Test the Validity and Reliability of Quantitative Research Instruments]. Jurnal Tarbiyah: Jurnal Ilmiah Kependidikan, $\quad 7(1), \quad$ 17-23. https://doi.org/10.18592/tarbiyah.v7i1.2100

Zhou, D., Du, X., Hau, K. T., Luo, H., Feng, P., \& Liu, J. (2020). Teacher-student relationship and mathematical problem-solving ability: mediating roles of selfefficacy and mathematical anxiety. Educational Psychology, 40(4), 473-489. https:// doi.org/10.1080/01443410.2019.1696947 


\section{Appendix 1}

Sample of mathematical anxiety instrument filled by a respondent.

Name

: Revan

Class

: VI.A

Name of school

: Wantilan National Elementary School

Instructions:

1. Read each statement carefully. Please kindly ask the teacher if you have difficulties in understanding the statement.

2. Put a check mark ( ) on the response that corresponds to what you experience and feel. Response choices are:

$\mathrm{SA}=$ Strongly Agree

$\mathrm{A}=$ Agree

$\mathrm{D}=$ Disagree

$\mathrm{SD}=$ Strongly Disagree

3. Do the questionnaire on your own.

4. Once you are sure of your response, you can submit this questionnaire to your teacher.

5. Your response to this questionnaire will not affect your grades.

\begin{tabular}{|c|c|c|c|c|}
\hline \multirow{2}{*}{ Statement } & \multicolumn{4}{|c|}{ Response } \\
\hline & SA & $\mathbf{A}$ & D & SD \\
\hline $\begin{array}{l}\text { 1. I often skip school when it is a mathematics schedule, } \\
\text { especially when the learning is about geometry that } \\
\text { has a lot of calculations. }\end{array}$ & & & & \\
\hline $\begin{array}{l}\text { 2. I always present in Mathematics subject because in } \\
\text { my opinion Mathematics is a challenging subject, } \\
\text { especially when discussing geometry with many } \\
\text { calculations. }\end{array}$ & & & & \\
\hline $\begin{array}{l}\text { 3. In every Math lesson, I prefer to sit at the very back } \\
\text { row, because the back seat is not visible to the teacher } \\
\text { so I am sure I will not be appointed to come forward. }\end{array}$ & & & & \\
\hline $\begin{array}{l}\text { 4. I always want to sit in the front so that I can listen to } \\
\text { the geometry material taught by my teacher. }\end{array}$ & & & & \\
\hline $\begin{array}{l}\text { 5. I always ask my teacher, if there is geometry material } \\
\text { that I do not understand. }\end{array}$ & & & & \\
\hline $\begin{array}{l}\text { 6. I never answer questions about geometry, which is } \\
\text { difficult for me. }\end{array}$ & & & & \\
\hline $\begin{array}{l}\text { 7. No matter how difficult the question about geometry } \\
\text { is, I always try to do it }\end{array}$ & & & & \\
\hline $\begin{array}{l}\text { 8. Every time I get a question about geometrical volume, } \\
\text { it always difficult to solve the question because there } \\
\text { are many numbers that I have to calculate }\end{array}$ & & & & \\
\hline $\begin{array}{l}\text { 9. I have no difficulty in doing questions about } \\
\text { geometrical volume because I am always careful in } \\
\text { calculating the numbers. }\end{array}$ & & & & \\
\hline $\begin{array}{l}\text { 10. I always refuse every time the teacher appoints me to } \\
\text { go forward to answer questions about geometry in } \\
\text { front of the class because I am afraid my friends will } \\
\text { laugh at me when my answer is wrong. }\end{array}$ & & & & \\
\hline 11. I answered the question in front of the class with & & & & \\
\hline
\end{tabular}




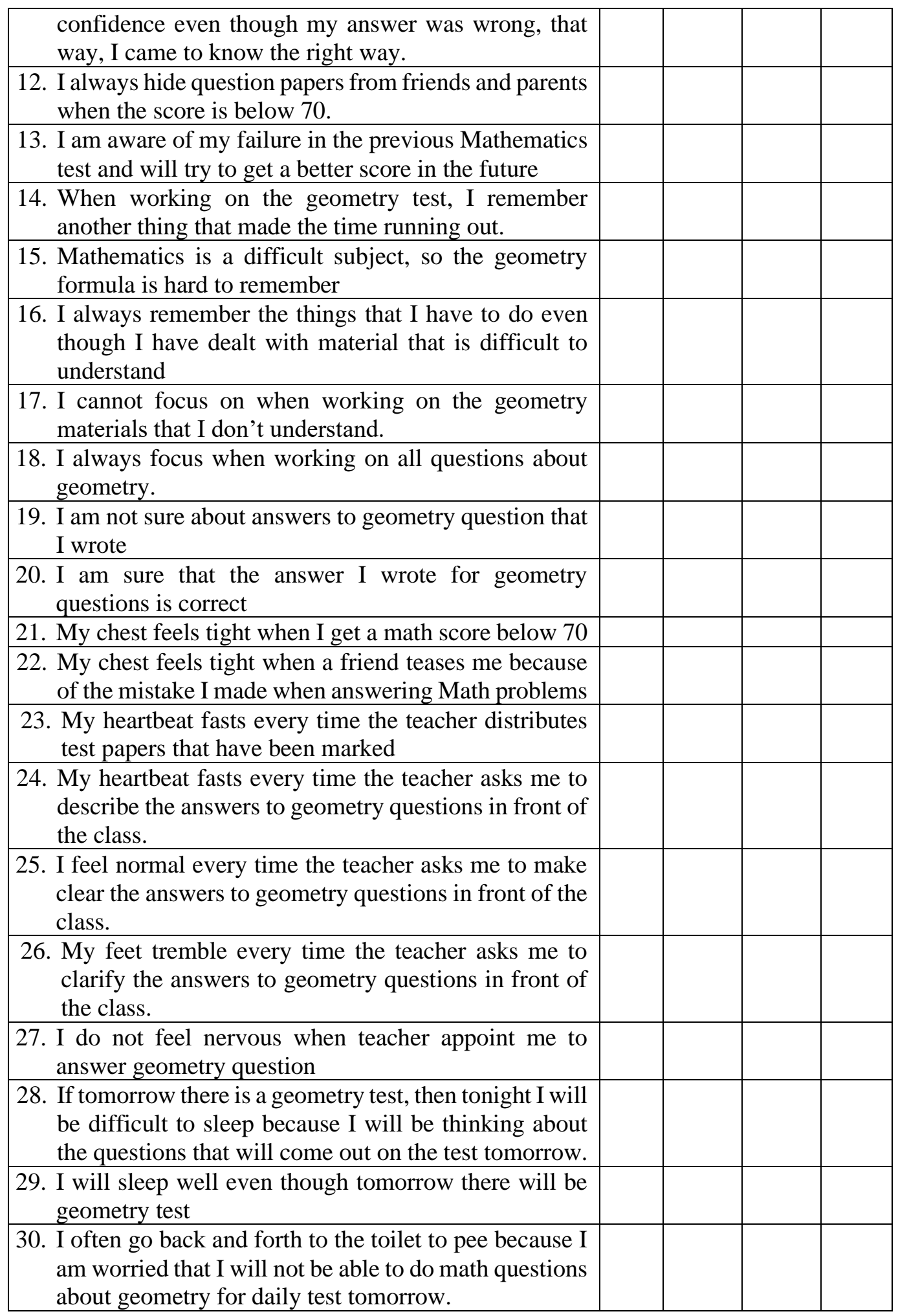

